\title{
Comparison of one-step and step-wise compression tests
}

\section{Šarūnas Skuodis ${ }^{1}$}

\author{
Ahmet Habib Karaman², \\ Neringa Dirgèlien $\dot{e}^{3}$ \\ 1,3 Vilnius Gediminas Technical University, \\ Faculty of Civil Engieneering, \\ Department of Geotechnical Engineering, \\ Saulètekio al. 11, \\ LT-10223 Vilnius, Lithuania \\ E-mailsarunas.skuodis@vgtu.lt \\ ${ }^{2}$ Erzincan University, \\ Faculty of Engineering, \\ Department of Civil Engineering, \\ Fatih Mahallesi, \\ 24100 / ERZINCAN, Turkey
}

\begin{abstract}
Skuodis Š., Karaman A. H., Dirgèlienè N. Comparison of one step and step wise compression tests. Geologija. Geografija. 2017. T. 3(1). ISSN 2351-7549.

The primary purpose of this paper is to investigate the influence of loading procedure type. To reach this aim, we have chosen the Baltic Sea Klaipeda sand, due to granulometry composition and particles shape. The paper examines several key aspects of sand compression type, namely comparison between one-step (constant rate loading) and step-wise (incremental loading) oedometer compression tests. In this manuscript, we present investigation of sandy soil compression character up to maximum $400 \mathrm{kPa}$ loading. This research shows the difference between two loading procedures. The main objects of research: investigation of stress jumps during one-step and step-wise soil sample loading. The analysis of the results shows that when soil was compressed by step-wise loading procedure $(0.94 \mathrm{~mm})$ displacements were almost twice as big as in case of one-step loading procedure $(0.57 \mathrm{~mm})$.
\end{abstract}

Keywords: oedometer, one-step loading, step-wise loading, sand compression

\section{INTRODUCTION}

Soil compressibility parameters and their usage, which are needed for designers and constructors, are obtained in each construction site while examining physical and mechanical properties of soils. Soil compressibility parameters and using them in determination of soil settlements usually are defined with some inaccuracies. Having knowledge about these inaccuracies, disadvantages of testing equipment could be eliminated, methodology of data evaluation could be developed, soil parameters could be determined more precisely, and foundations could be designed more economically.

Experimental investigations don't answer to many questions, so numerical modelling is a very important investigation method for soil mechanical parameters and behaviour. Mathematical models have to reflect physical and mechanical points of soil (Cundal, Strack, 1979), so it's a nec- essary experience and engineering idea. Recently, the discrete element method (DEM) has gained attention to model irregular particle morphology. The study of particle morphology plays an important role in understanding the micromechanical behaviour of cohesionless soil. Mechanical behaviour of granular soil depends on various morphological characteristics of soil grains such as their particle size, shape and surface texture. Therefore, accurate characterization and quantification of particle shape is necessary to study the effect of grain shape on mechanical behaviour of granular assembly. Reliability and accuracy of numerical DEM modelling for sand soil behaviour depends on the modelled soil and discretization level of particles (Bono, McDowell, 2015).

In this research work, we present only the experimental part of oedometer compression tests of sand from Klaipeda, concentrating on the compression curve character. The soil compression curve mostly obtained in literature 
is presented as a void ratio and normal stress dependence (Uygar, Doven, 2006). Other authors present soil compression curves with vertical loading from 5 to $10 \mathrm{kPa}$ (Comina et al., 2008; Shipton, Coop, 2012). In this case, it is not necessary to show what happens with the soil compression curve when vertical stress is from 0 to 5 or $10 \mathrm{kPa}$.

The main idea of this research work is to show the importance of results obtained with one-step (CRL, constant rate of loading) and step-wise (IL, incremental loading) loading tests procedures. The morphological parameters of investigated sand grains for discrete model creation have been determined earlier (Skuodis et al., 2014). Therefore, the primary purpose of this article is to investigate the influence of loading procedure type on future numerical simulations with DEM of oedometer test.

In Lithuania, for shallow foundations or pile (pile group) settlements calculations, the Summing method is usually used (Vitale, Skuodis, 2013; Sližytè et al., 2012). This method is mostly used, because the calculated settlement according to common soil types which are in Lithuania is having the best matching with real settlements of engineering structures foundations. Nevertheless, usually the settlement calculated with the Summing method is slightly different from the real settlement of the engineering structure or building. According to this difference of settlements, research work was conducted in order to simulate step-wise (Bo et al., 2015) foundation load increment as it is in the site and to compare the obtained results with one-step loading. The maximum stress value chosen for experimental investigations was $400 \mathrm{kPa}$. This loading covers almost all typical Lithuanian buildings loads (according to building life cycle stages (WBSCD, 2007): production, construction and use) transfer on foundations, which are transmitting upper structure stress range for soil (Archer, Heymann, 2015).

Each continent or country has the most investigated soil type (sand, clay, etc.) which can be called the standard soil type. Standard sand is high quality silica sand that is free of organic matter and is used in making tests (Ojuri, Agbolade, 2015). For example in Great Britain it is a very famous London clay (Tsiampousi et al. 2016), in Norway - quick clay (Solberg et al., 2016), in the USA - Ottawa sand (Guo, Su, 2007), in Nigeria - Igbokoda sand (Ojuri, Agbolade, 2015), in Korea - Jumunjin sand (Kim et al., 2016), in China - Fujian sand (Pei-Yong, Qing, 2009), etc. The Lithuanian standard sand for scientific testing can be the Baltic Sea Klaipeda sand, due to granulometry composition and particles shape (Medzvieckas et al., 2008; Skuodis et al., 2014; Dundulis, Gadeikis, 2006). This is the reason why Klaipeda sand was chosen for one-step and stepwise tests comparison.

\section{EXPERIMENTAL SETUP}

The investigated area is located in the southern part of the Lithuanian mainland area of the Baltic Sea (the northern part of Klaipeda city). Northwards from Klaipeda city, only the immediate near-coast area contains a sandy strip of Holocene marine sediments (m IV), which occur as deep as to $4-5$ meters in the sea (Česnulevičius et al., 2017; Skuodis et al., 2014). The mineralogical composition of sand under investigation was determined by Amšiejus et al. (2010), where sand was found to contain $\sim 85 \%$ of quartz and $\sim 6 \%$ of feldspar with the remaining contribution of carbonate, mica and some other minerals. The obtained granulometric curve of investigated sand is presented in Fig. 1. Sand uniformity coefficient is $C_{U}=1.47$ and coefficient of curvature is $C_{C}=0.93$ (according to ISO 14688-2). These parameters represent the shape of the grading curve and denote the even-graded granulometric curve.

The average density of particles $\left(\rho_{s}\right)$ varied from 2.65 to $2.67 \mathrm{~g} / \mathrm{cm}^{3}$ (Dundulis et al., 2006). Mean (2D case) Klaipeda sand equivalent diameter $d_{\text {ekv }, 2 D}=0.340 \mathrm{~mm}$, form coefficient $K_{f, 2 D}=0.702$ (Skuodis et al., 2014).

The compression tests were performed with a fully automatic oedometer test device (Fig. 2). During testing, prepared sample height was $3.39 \mathrm{~cm}$ and diameter $7.14 \mathrm{~cm}$. Sample bulk density $(\rho)$ varied from 1.74 to $1.76 \mathrm{~g} / \mathrm{cm}^{3}$, with water content $W=4.00 \%$.

Testing procedures were run with controlled load increment up to the maximum load of $400 \mathrm{kPa}$. For one-step loading testing procedure, the load ramp was $400 \mathrm{kPa} / \mathrm{min}$, the same load ramp was used and for step-wise testing procedure. 


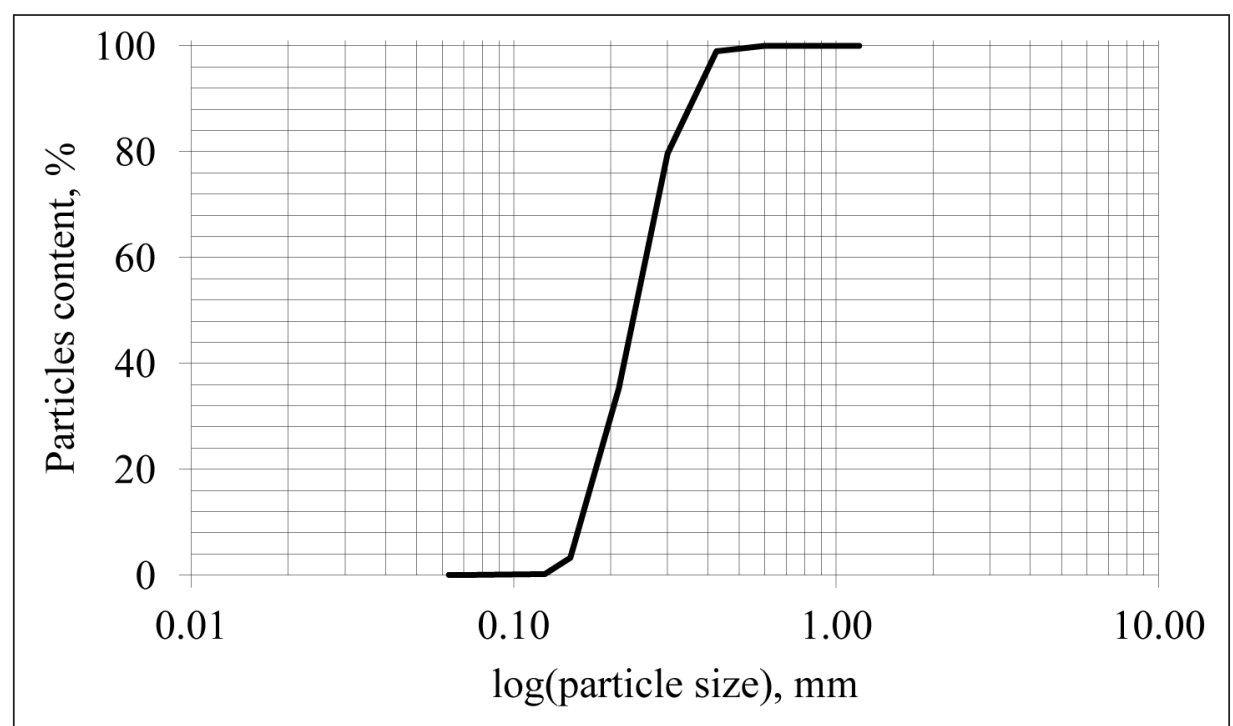

Fig. 1. Granulometry composition of investigated sand

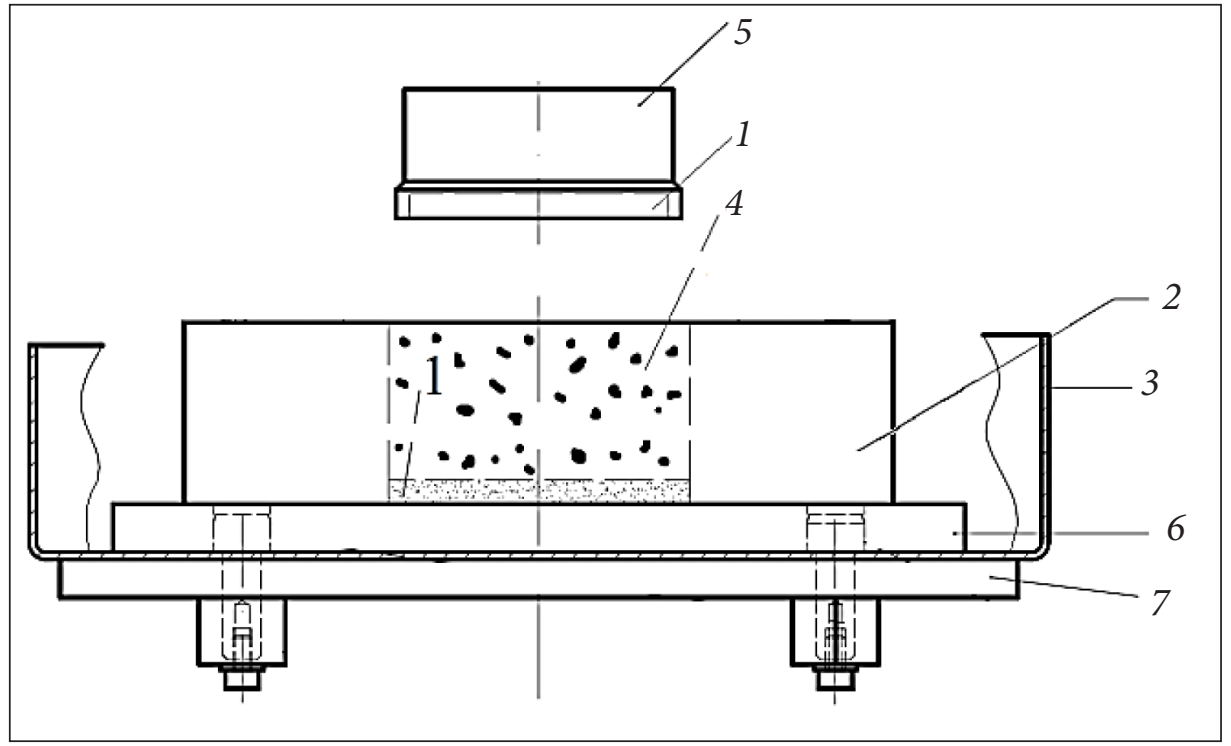

Fig. 2. Universal oedometer test device: 1 - porous stone, 2 - oedometer ring, 3 - water bath, 4 - sample, 5 - load piston ( $S$-type full bridge load transducer), 6 - oedometer ring orientation plate, 7 - oedometer base plate

Step-wise testing procedure consisted of 5 different loading steps, namely 50, 100, 200, 300, and $400 \mathrm{kPa}$. When each loading step was reached, the vertical load was kept for 15 minutes and only then another load step was applied (Schiffman et al., 1969; Negahdar et al., 2015).

For comparison of testing procedures, 12 onestep and 12 step-wise loading tests were performed. The decision to use load ramp $400 \mathrm{kPa} /$ min was accepted after several tests, where the influence of load ramp $(25,50,100,200,300,400$, $800 \mathrm{kPa} / \mathrm{min}$ ) on compression curve character was investigated (Fig. 3). In all different rate of loading cases, the vertical stress of $400 \mathrm{kPa}$ was reached.

According to results presented in Fig. 3 (Skuodis, Norkus, 2012), loading ramp did not have any influence on compression curve. During load ramp. stress jumps at $50-100 \mathrm{kPa}$ were obtained. The major repositioning of particles was observed near the top of the sample, where the main particles repositioning occurred, which is explained by Skuodis et al. (2014).

Knowing that load ramp from 25 to $800 \mathrm{kPa} /$ min has no influence on compression curve, there 


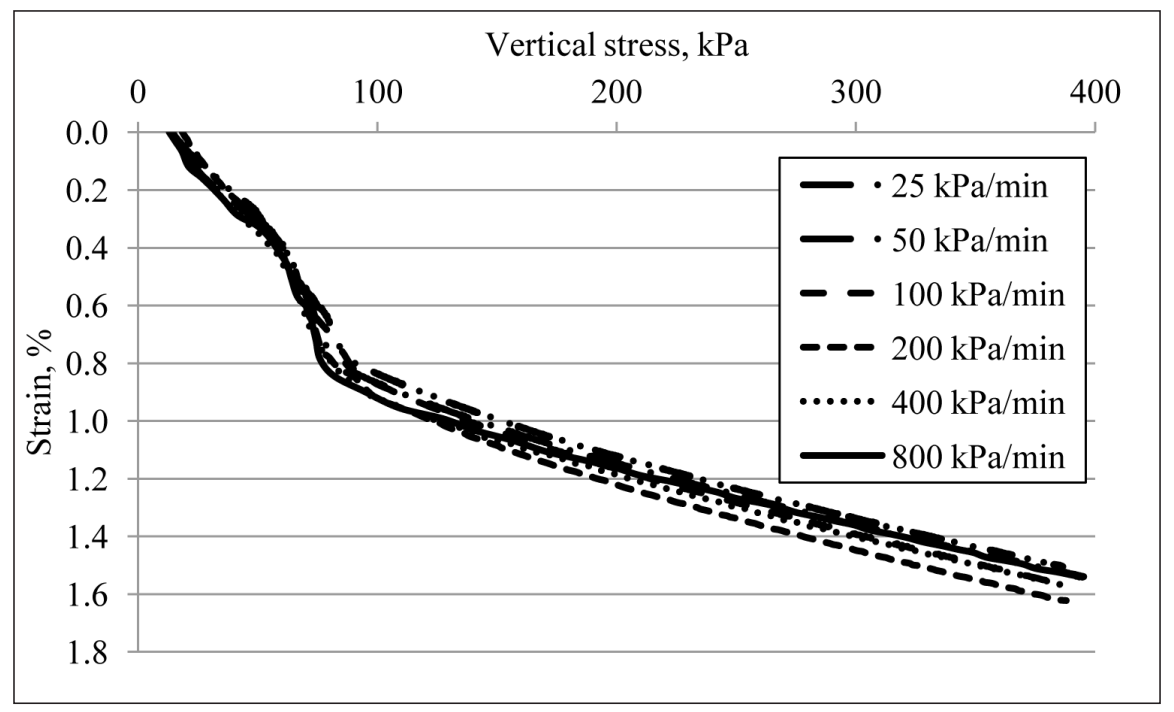

Fig. 3. Load ramp influence on air-dry sand compression results according to Skuodis, Norkus (2012)

was made a decision in this current research work to use load ramp $400 \mathrm{kPa} / \mathrm{min}$ (Suescun-Florez, Iskander, 2015; Druckrey et al., 2017; Parab et al., 2014).

\section{ANALYSIS OF OBTAINED RESULTS}

First of all, we analysed continuous one-step loading tests results (Fig. 4). 12 experiments for one-step loading procedure using the load ramp of $400 \mathrm{kPa} / \mathrm{min}$ were carried out. The stress jumps were not so expressed (Barr et al., 2014) as it is presented in Fig. 3, because in this investigation soil samples with water content $W=4.00 \%$ were used. Obtained inaccuracies at the low vertical stresses (at the sample and porous stone contact) are explained by Skuodis and Šlečkuvienè (2013). In this case, the loading piston with porous stone seeks to get in contact with the sample, and testing procedure recognises a contact between the sample and porous stone when the vertical stress value is at least $10 \mathrm{kPa}$. The same inaccuracies were obtained for step-wise loading tests too (Fig. 5).

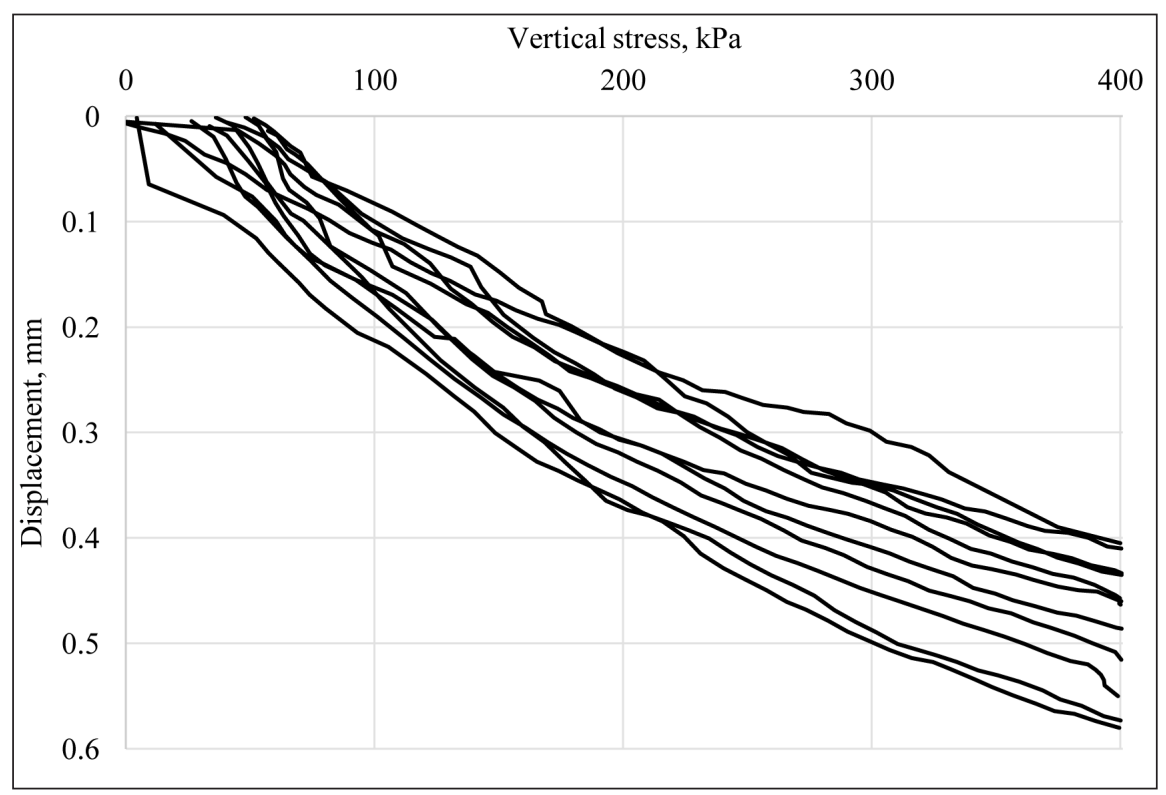

Fig. 4. Continuous one-step loading results 


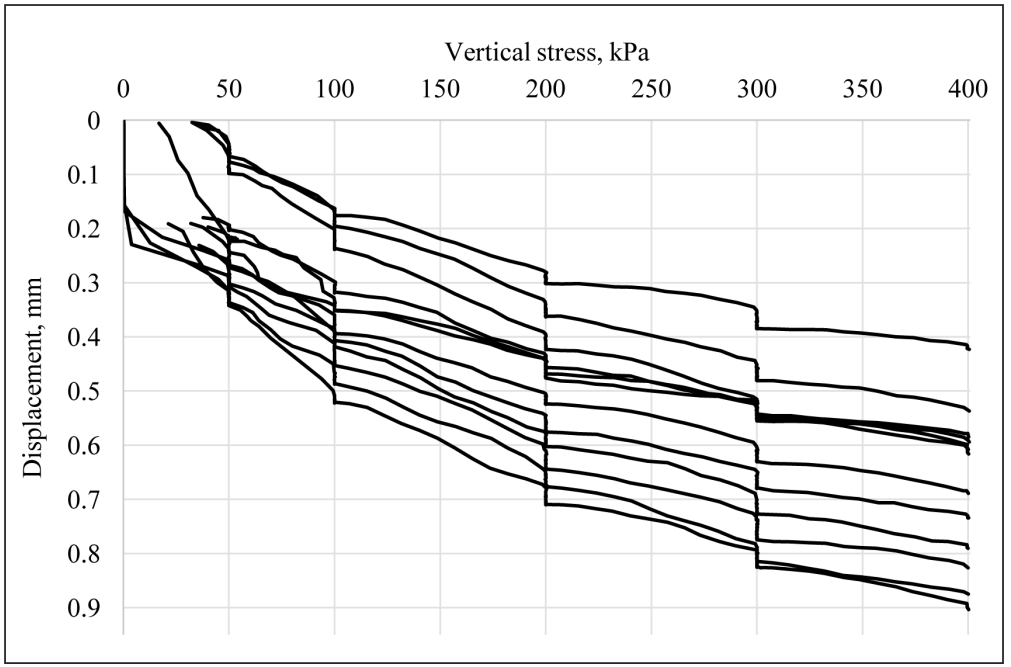

Fig. 5. Step-wise loading results

The step-wise testing procedure consisted of 5 different loading steps: 50, 100, 200, 300, and $400 \mathrm{kPa}$. When each loading step was reached, the vertical load was kept for 15 minutes and only then the other load step was applied. 12 experiments for step-wise loading procedure using load ramp of $400 \mathrm{kPa} / \mathrm{min}$ were carried out (Fig. 5).

From comparison of results obtained by onestep (Fig. 4) and step-wise (Fig. 5) loading procedures we see that the sample compaction process appeared for step-wise loading testing (during 15 min of constant vertical stress load, after each of 5 different loading steps is reached). Additional sample compaction leads to displacements increment at different step loading stresses (Fig. 6).

Analyzing results presented in Fig. 6 we see that, higher displacements increment magnitudes of $0-0.053 \mathrm{~mm}$ were obtained for low stresses (50 and $100 \mathrm{kPa}$ ) and lower displacements increment magnitudes of $0.01-0.04 \mathrm{~mm}$ for higher stresses $(200,300$, and $400 \mathrm{kPa})$. Before testing, it was assumed that almost all displacements reach their final magnitudes in first 5 seconds when load is applied (Skuodis, Amšiejus, 2011). A detailed compression behaviour of sand samples loaded with different loading steps is presented in Figs. 7-11. In these figures we can see displacements increment at different loads $(50,100,200$, $300,400 \mathrm{kPa}$ ) during $15 \mathrm{~min}$ (12 experiments were carried out).

Analysis of different loading steps' preloading time of 15 min (Figs. 7-11) showed that the examined sand soil was reacting differently at different loading steps stresses. That is a very important

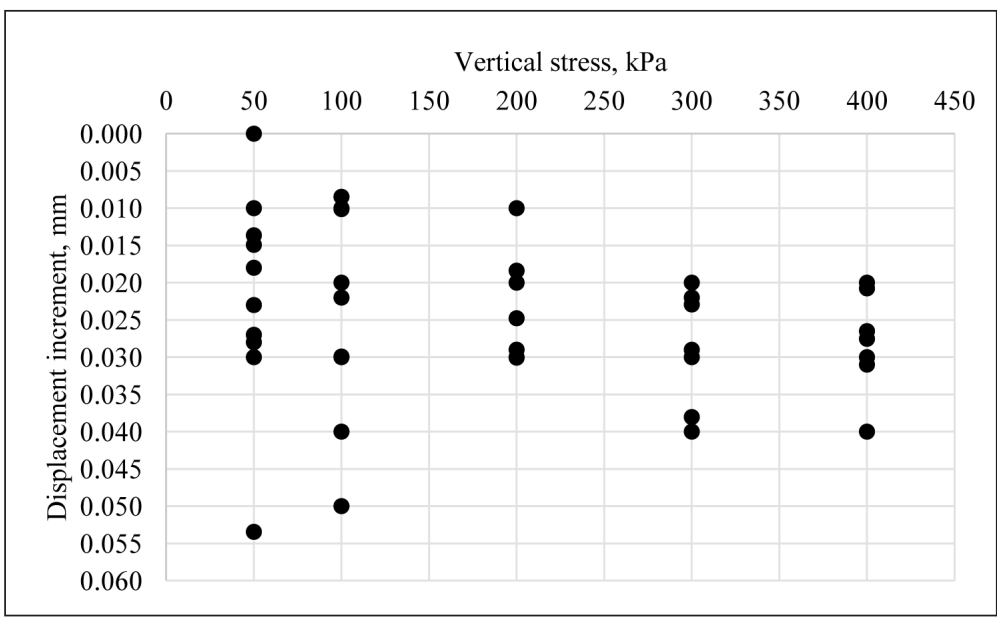

Fig. 6. Total displacements increment at different step loading stresses 


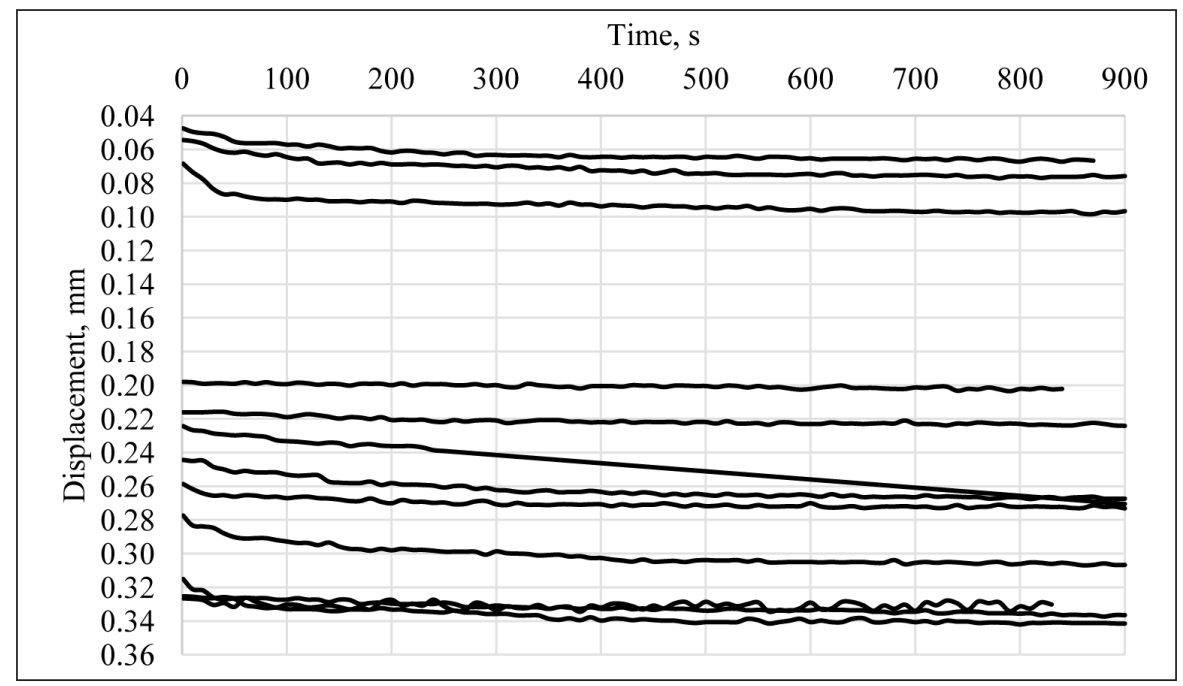

Fig. 7. Displacements increment at the $50 \mathrm{kPa}$ loading step

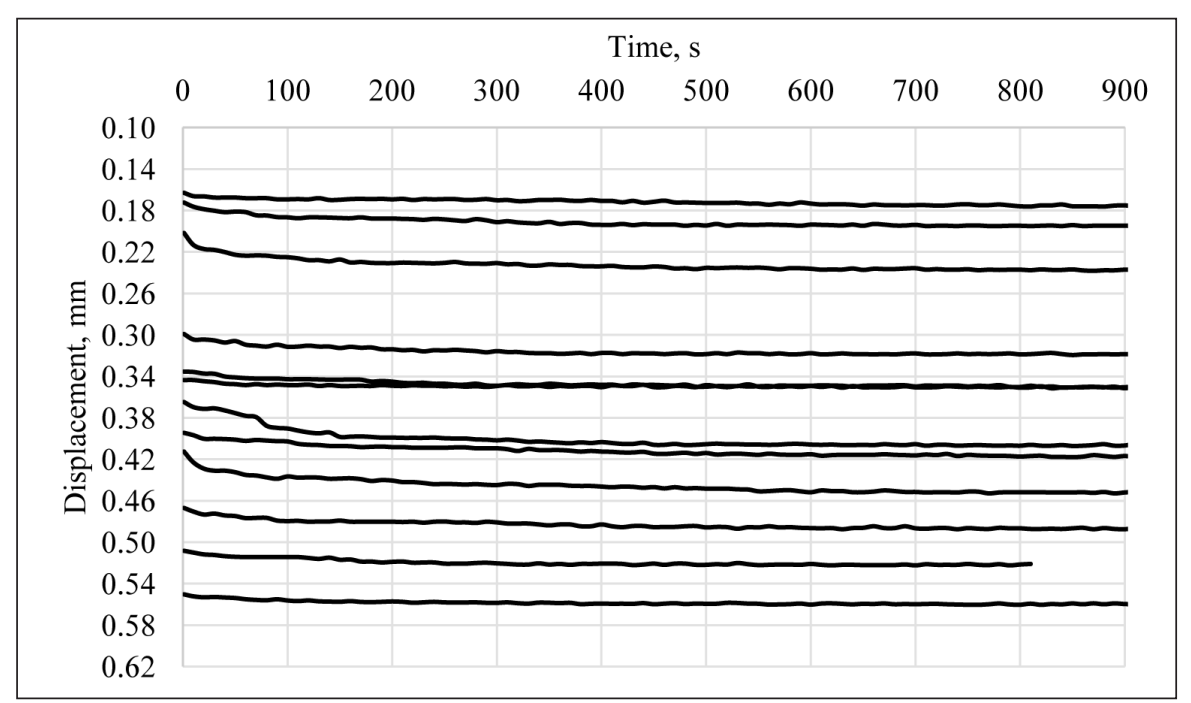

Fig. 8. Displacements increment at the $100 \mathrm{kPa}$ loading step

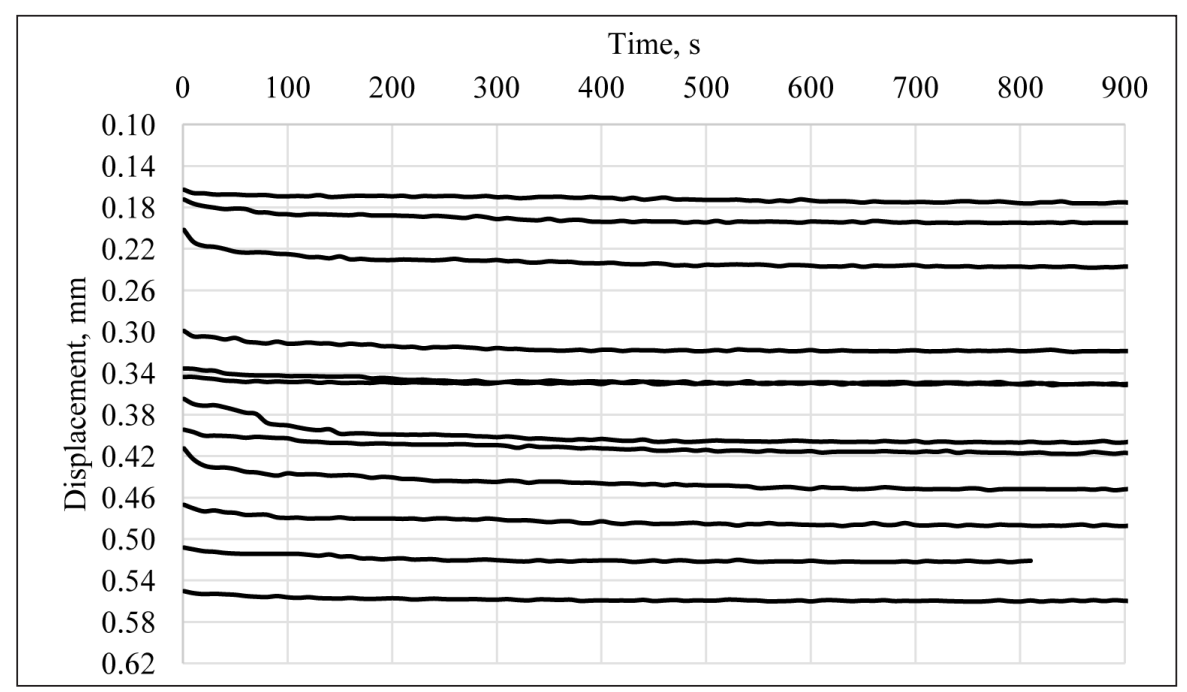

Fig. 9. Displacements increment at the $200 \mathrm{kPa}$ loading step 


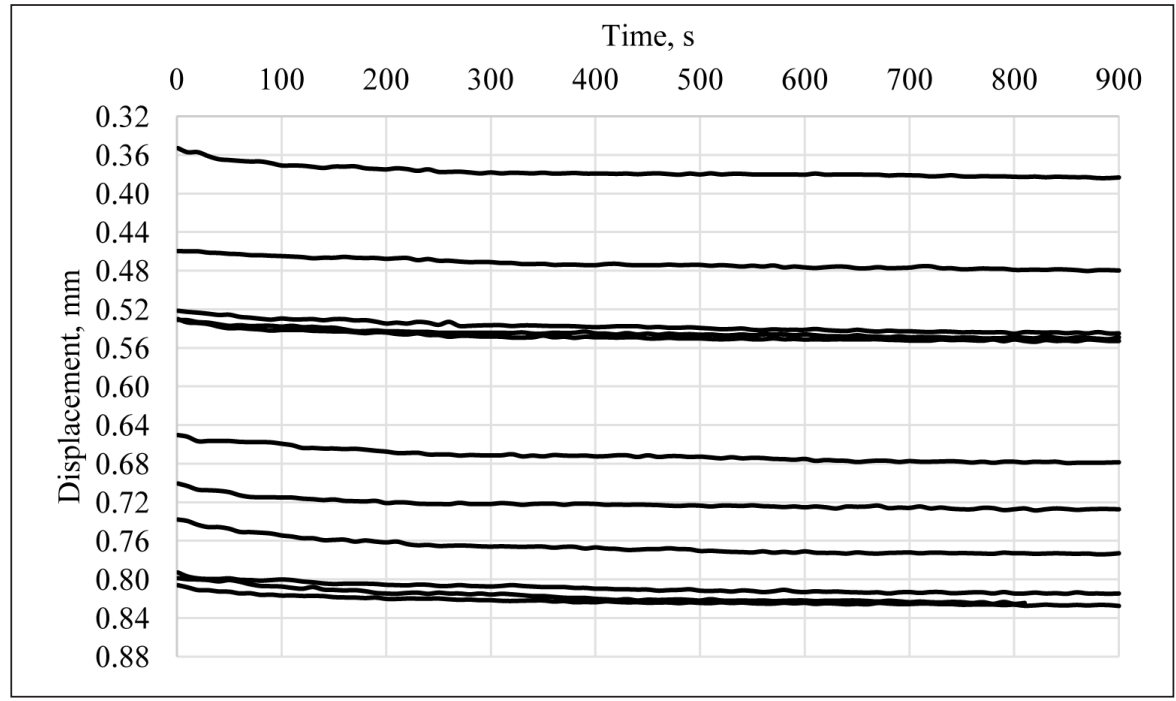

Fig. 10. Displacements increment at the $300 \mathrm{kPa}$ loading step

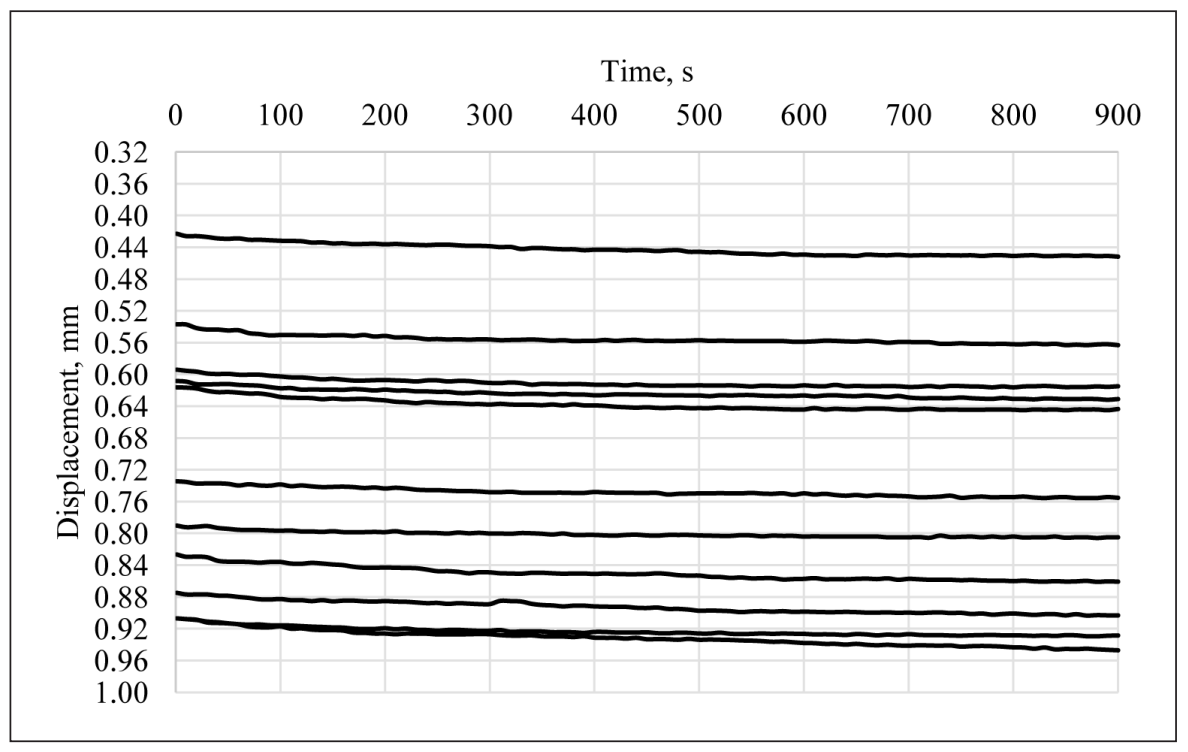

Fig. 11. Displacements increment at the $400 \mathrm{kPa}$ loading step

fact when experimental results are validated with numerical results. From analysis of experiments results obtained we see that when soil was compressed by step-wise loading procedure $(0.94 \mathrm{~mm})$ displacements were almost twice as big as in case of one-step loading procedure $(0.57 \mathrm{~mm})$. Total obtained displacement difference for different loading procedures was $0.37 \mathrm{~mm}$.

\section{CONCLUDING REMARKS}

The primary purpose of this paper was to investigate the influence of loading procedure type for future investigations on numerical simulations of oedometer test with the discrete element method. The current research concentrated on detailed experimental investigations of Klaipeda sand compression with the oedometer test device. The Baltic Sea Klaipeda sand was chosen due to granulometry composition and particles shape. This research shows the difference of one-step and step-wise loading procedures. The obtained results revealed that step-wise and one-step loading procedures lead to different results even when sandy soil is tested. Analysis of one-step loading tests revealed that there were no stress jumps for sand with water content $W=4.00 \%$. Stress jumps were obtained only in air-dry sand compression 
tests results. For step-wise loading testing, we obtained a higher displacements magnitudes dispersion at low stresses (50 and $100 \mathrm{kPa}$ ) and a lower displacements magnitudes dispersion at higher stresses $(200,300$, and $400 \mathrm{kPa})$. This effect of stress jumps is similar to that obtained for air-dry soil testing, only in this case stress is constant, but displacement is increasing. Displacement increment is explained as particles repositioning effect (according to literature analysis). This research work represents only one soil type (sand). For other soil types as clay, silt, etc., it is not possible to apply obtained results. The influence of the above-mentioned factors, contributing to the accuracy of numerical modelling, is a future trend.

\section{ACKNOWLEDGEMENTS}

The equipment and infrastructure of Civil Engineering Research Centre of Vilnius Gediminas Technical University were employed for investigations.

Received 24 February 2017 Accepted 11 April 2017

\section{References}

1. Amšiejus J., Kačianauskas R., Norkus A., Tumonis L. 2010. Investigation of sand porosity via oedometric testing. The Baltic Journal of Road and Bridge Engineering. 5(3); 139-147.

2. Archer A., Heymann G. 2015. Using smallstrain stiffness to predict the load-settlement behaviour of shallow foundations on sand. Journal of the South African Institution of Civil Engineering. 57(2): 28-35.

3. Barr A. D., Clarke S. D., Petkovski M., Tyas A., Warren J. 2014. Proceedings of the TC105 ISSMGE International Symposium on Geomechanics from Micro to Macro. Cambridge.

4. BoM.W., Wong K.S., ChoaV., Arulrajah A., Horpibulsuk S. 2015. Step loading compression of ultra-soft soil under radial drainage conditions. Marine Georesources \& Geotechnology. 34(7): 648-658.

5. Bono J. P., McDowell G. R. 2015. An insight into the yielding and normal compression of sand with irregularly-shaped particles using DEM. Powder Technology. 271: 270-277.

6. Comina C., Fotti S., Musso G., Romero E. 2008. EIT Oedometer: An advanced cell to monitor spatial and time variability in soil with electrical and seismic measurements. Geotechnical Testing Journal. 31(5): 1-9.

7. Cundal P. A., Strack O. D. L. 1979. A discrete numerical model for granular assemblies. Geotechnique. 29: 47-65.

8. Česnulevičius A., Morkūnaitè R., Bautrènas A., Bevainis L., Ovodas D. 2017. Intensity of geodynamic processes in the Lithuanian part of the Curonian Spit. Earth System Dynamics Discussions. doi:10.5194/esd-20173, in review, 2017.

9. Druckrey A., Casem D., Alshibli K., Huskins E. 2017. Influence of loading rate on fracture strength of individual sand particles. Proceedings of the 2016 Annual Conference on Experimental and Applied Mechanics. USA.

10. Dundulis K., Gadeikis S. 2006. Influence of morphometric characteristics of sand particles on the strength parameters of sand soils in Lithuania. Geologija. 53: 52-56.

11. Dundulis K., Gadeikis S., Gadeikytè S., Račkauskas V. 2006. Sand soils of Lithuanian coastal area and their geotechnical properties. Geologija. 53: 47-51.

12. Guo P., Su X. 2007. Shear strength, interparticle locking, and dilatancy of granular materials. Canadian Geotechnical Journal. 44(5): 579-591.

13. ISO 14688-2:2004. Geotechnical investigation and testing - Identification and classification of soil - Part 2: Principles for a classification.

14. Kim J., Choi Ch., Kang J., Baek W., Chung M. 2016. Model test for the observation of cavity formation in sandy ground - with reference to ground water level and relative density. Japanese Geotechnical Society Special Publication, The 6th Japan-Korea Geotechnical Workshop. 64-67.

15. Medzvieckas J., Gadeikis S., Dundulis K. 2008. Properties of fine soils of Klaipeda Port area. Geologija. 50(3): 206-211.

16. Negahdar A., Yadegari Sh., Houshmandi S. 2015. Experimental study of the effect of stress level on time dependent deformation of sandy clay soil. Japanese Geotechnical Society Special Publication. 2(11): 457-460. 
17. Ojuri O. O., Agbolade O. C. 2015. Improvement of engineering properties of Igbokoda standard sand with shredded polyethylene wastes. Nigeria Journal of Technology. 34(3): 443-451.

18. Parab N. D., Claus B., Hudspeth M. C., Black J. T., Mondal A., Sun J., Fezzaa K., Xiao X., Luo S. N., Chen W. 2014. Experimental assessment of fracture of individual sand particles at different loading rates. International Journal of Impact Engineering. 68: 8-14.

19. Pei-Yong L., Qing Y. 2009. The study on soilwater characteristic curve of bentonite-sand mixtures. Electronic Journal of Geotechnical Engineering. 14: 1-8.

20. Schiffman R. L., Chen A. T. F., Jordan J. C. 1969. An analysis of consolidation theories. Journal of Soil Mechanics and Foundation. 95: 285-312.

21. Shipton R., Coop M. R. 2012. On the compression behaviour of reconstituted soils. Soils and Foundations. 52(4): 668-681.

22. Skuodis Š., Amšiejus J. 2011. Skirtingų smèlio frakcijų spūdumo tyrimas kompresiniu apratu. Engineering Structures and Technologies. 3(1): 16-22 [in Lithuanian].

23. Skuodis Š., Markauskas D., Norkus A., Žaržojus G., Dirgèlienè N. 2014. Testing and numerical simulation of Holocene marine sand uniaxial compression at Lithuanian coast. Baltica. 27(1): 33-44.

24. Skuodis Š., Norkus A. 2012. Kontroliuojamu slègiu apkraunamo smèlinio grunto spūdumo tyrimas. Proceedings of the 15th Conference for Junior Researchers "Science - Future of Lithuania". Vilnius [in Lithuanian].
25. Skuodis Š., Šlečkuvienė A. 2013. Universalaus spūdumo ir paprastojo kirpimo aparato, kontakto vietos tarp porinio akmens ir grunto tikslesnis nustatymo būdas. Mokslas - Lietuvos ateitis. 5(5): 520-524 [in Lithuanian].

26. Sližytė D., Medzvieckas J., Mackevičius R. 2012. Pamatai ir pagrindai. Vilnius: Technika. 248 p. [in Lithuanian].

27. Solberg I. L., Long M., Baranwal V. Ch., Gylland A. S., Ronning J. S. 2016. Geophysical and geotechnical studies of geology and sediment properties at a quick-clay landslide site at Esp, Trondheim, Norway. Engineering Geology. 208: 214-203.

28. Suescun-Florez E., Iskander M. 2015. A model to predict strain rate dependency of dry silica sand in triaxial compression. Journal of Dynamic Behaviour of Materials. 1(4): 447-461.

29. Tsiampousi A., Zdravkovic L., Potts D. M. 2016. A numerical study of the effect of soil atmosphere interaction on the stability and serviceability of cut slopes in London clay. Canadian Geotechnical Journal. 10.1139/cgj2016-0319, in review 2016.

30. Uygar E., Doven A. G. 2006. Monotonic and cyclic oedometer tests on sand at high stress levels. Granular Matter. 2006(8): 19-26.

31. Vitale P., Skuodis Š. 2013. Analysis of shallow foundations settlements via different calculations methods. Proceedings of the 16th Conference for Junior Researchers "Science - Future of Lithuania". Vilnius.

32. World Business Council for Sustainable Development (WBCSD), 2007. Energy Efficiency in Buildings, Business Realities and Opportunities. Full Report. Geneva: WBCSD. 
Šarūnas Skuodis, Ahmet Habib Karaman, Neringa Dirgèlienè

\section{VIENOS PAKOPOS IR PAKOPINIO SPŪDUMO BANDYMŲ PALYGINAMIEJI BANDYMAI}

\section{Santrauka}

Straipsnis skirtas vienos pakopos ir pakopinio grunto spūdumo bandymų palyginimui. Poreikis atlikti tokius bandymus kilo dèl dviejuc pagrindinių priežasčių: praktinio taikymo prognozuojant pamatų nuosėdžius ir skaitinio bandymų modeliavimo. Bandymai atlikti spaudžiant smélinị gruntą su odometriniu aparatu dviem skirtingomis metodikomis: vienos nepertraukiamos pakopos spūdumo bandymas (iki didžiausios $400 \mathrm{kPa}$ ) apkrovos ir pakopinis apkrovimas (iki didžiausios $400 \mathrm{kPa}$ ) išlaikant skirtingas pakopu apkrovas 15 min. ir tik tada didinant apkrovą. Pakopiniam apkrovimui naudoti 50; 100; 200; 300 ir $400 \mathrm{kPa}$ apkrovų pakopų žingsniai. Visi spūdumo bandymai atlikti su Baltijos jūros pakrantès paplūdimio smèliu, kurio tankis $\rho=1,74-1,76 \mathrm{~g} / \mathrm{cm}^{3}$, drègnis $\mathrm{W}=4 \%$ ir naudojant $400 \mathrm{kPa} / \mathrm{min}$. apkrovimo greitị. Šis gruntas dèl granuliometrinès sudèties ir dalelių morfologinių parametrų gali būti vadina- mas etaloniniu Lietuvos smèliu, tinkančiu atlikti palyginamuosius bandymus. Kadangi bandymai atlikti su smèliniu gruntu, tikètasi, kad bandymų metodikos neturès įtakos rezultatams. Iš literatūros analizès buvo žinoma, kad smèlinis gruntas deformuojasi per pirmas 3-5 sekundes po apkrovimo, todèl poslinkiu atsiradimas esant pakopiniam apkrovimui nebuvo tiketinas. Tačiau atlikti bandymai atskleide, kad išlaikant pakopines apkrovas 15 min. poslinkiai vis dèlto atsiranda. Dèl šios priežasties praktiškai dvigubai skiriasi poslinkiai nustatyti atliekant vienos pakopos $(0,57 \mathrm{~mm})$ ir pakopinio $(0,94 \mathrm{~mm})$ spūdumo bandymus. Didesnè nustatytų poslinkių rezultatų dispersija vyrauja prie mažų įtempių, $50-200 \mathrm{kPa}$ (pakopiniam apkrovimui). Šis efektas paaiškinamas dalelių pozicijų pasikeitimu, todèl ir buvo nustatytas nedidelis ittempių šuolis (50-200 kPa) atliekant vienos pakopos spūdumo bandymus iki didžiausios pasirinktos $400 \mathrm{kPa}$ apkrovos. Dažniausiai šie įtempių šuoliai pasireiškia, kai spaudžiamas orasausis gruntas.

Raktažodžiai: odometras, vienos pakopos spūdumo bandymai, pakopiniai spūdumo bandymai, grunto kompresija 